\title{
Kuasa Pasar Dalam Pembentukan Identitas Aceh: Renegosiasi Identitas Lokal dalam Praktik Komersialisasi dan Konsumerisme Pasca Konflik dan Tsunami di Banda Aceh
}

Oleh

\author{
Ibnu Mujib, Irwan Abdullah'
}

\begin{abstract}
Abstrak
Tulisan ini menunjukkan proses renegosiasi identitas lokal dalam praktik komersialisasi dan konsumerisme di Aceh. Dua praktik sosial ini muncul di Aceh sebagai akibat dari proses ekspansi pasar yang meluas pasca tsunami. Di mana faktanya telah didukung oleh egen-egen globalisasi yang merepresentasi pemikiran-pemikiran dan etos kapitalisme. Tidak saja itu, bahkan praktiknya berlangsung sebagai ideologi gerakan, bukan sekadar sebagai bentuk-bentuk praktik ekonomi politik yang berlangsung secara normal dan seimbang. Di sinilah bentuk dominasi pasar faktanya telah terlalu kuat mendominasi masyarakat terutama bagi yang tidak memiliki kekuatan modal ekonomi, politik, dan akses distribusi yang cukup, negara telah begitu saja perannya dapat dibeli dengan kekuatan-kekuatan kapital yang berkuasa. Bahkan dampaknya sampai melahirkan pergeseran pada identitas Keacehan, seperti bagaimana masyarakat Aceh yang sebelumnya memegangi prinsip-prinsip kekeluargaan, kebersamaan, kesetiakawanan, kepedulian, dan bahkan egaliter, kemudian dipaksa dan dibenturkan pada tradisi baru yang meletakkan etos transaksional dengan mengedepankan prinsip-prinsip individual, serta bergantung pada sistem ekonomi kapitalistis.
\end{abstract}

Kata kunci: kuasa pasar, renegosiasi, identitas lokal, komersialisasi, dan konsumerisme, gaya hidup.

\begin{abstract}
This paper shows the process of renegotiation of local identity in the commercialization and consumerism process in Aceh. Two of these social practices emerging in Aceh as a result of widespread market expansion process after the tsunami. Where the fact has been supported by globalization represent the thoughts and ethos of capitalism. Even the practice takes place as ideological movement, not merely as forms of political economic practices that take place in a normal and balanced. Here comes from the fact that market dominance has been too strong to dominate the community, especially for those who do not have the strength of economic capital, political, and considerable distribution access, the state has granted the role can be purchased by the forces of capital in power. Even the shift in impact to the delivery of Acehnese identity, such as how the people of Aceh who previously held the principles of family, togetherness , solidarity , caring , and even egalitarian , then forced and bang it on a new tradition with a transactional ethos that put forward the principles of individual, as well as depends on the capitalistic economic system .
\end{abstract}

Keywords: market power, renegotiation, local identity, commercialization, consumerism, lifestyle

\footnotetext{
${ }^{1}$ Ibnu Mujib adalah kandidat Doktor program studi Agama dan Lintas Budaya, UGM, dan dosen Fak. Sosiologi pada Universitas Budiutomo Malang. Irwan Abdullah adalah Guru Besar Antropologi Fak. Ilmu Budaya UGM.
} 
Jurnal Pemikiran Sosiologi Volume 2 No. 2, 2013

Kuasa Pasar Dalam Pembentukan Identitas Aceh: Renegosiasi Identitas Lokal dalam Praktik Komersialisasi dan

Konsumerisme Pasca Konflik dan Tsunami di Banda Aceh

Ibnu Mujib, Irwan Abdullah

\section{A. Pendahuluan}

Perubahan sosial, ekonomi, dan politik yang terjadi secara meluas dalam masyarakat tidak saja menjelaskan bagaimana interaksi masyarakat dengan berbagai faktor lokalitas keacehan, tetapi perubahan masyarakat lokal harus juga dilihat sebagai perubahan global yang memiliki pengaruh dalam penataan sosial masyarakat (Abdullah, 2006: 142). Selain itu, perubahan di atas juga disebabkan oleh meluasnya globalisasi yang membutuhkan respon tepat dan cepat, serta memerlukan strategi yang tepat (Fatherstone, 1991, Hannerz, 1996). Proses yang demikian ini akan membawa pasar menjadi kekuatan dominan dalam pembentukan nilai dan penataan sosial dalam masyarakat. Tidak saja itu, pasar juga telah memperluas orientasi dan tingkat mobilitas masyarakatnya secara lebih intens, sehingga menyebabkan batas-batas sosial budaya masyarakat ikut mengabur.

Salah satu tanda masyarakat yang didominasi oleh kekuatan pasar adalah munculnya gejolak konsumerisme, yang diikuti oleh bentuk-bentuk komodifikasi identitats yang didukung dengan menguatnya media-media lokal baik cetak maupun elektronik. Masyarakat konsumer disebut Jean Baudrillard dengan masyarakat kapitalis mutakhir (Jean Baudrillard, 2005) dan Adorno dengan "masyarakat komoditas" (commodity society) (Benzer, 2001:109). Dengan demikian, mereka yang bekerja di media, desain, mode, dan periklanan serta para 'intelektual informasi' yang pekerjaannya adalah memberikan pelayanan serta memproduksi, memasarkan dan menyebarkan barang-barang simbolik disebut oleh Bourdieu (1984) sebagai 'perantara budaya baru' (Piliang dalam Ibrahim, 1997, hal. 200).

Budaya konsumerisme terutama muncul setelah masa industrialisasi, yaitu ketika barang-barang mulai diproduksi secara massal sehingga membutuhkan konsumen lebih luas. Media dalam hal ini menempati posisi strategis sekaligus menentukan; yaitu sebagai medium yang menjembatani produsen dengan masyarakat sebagai calon konsumen. Bahkan masalah ini dikaji secara teoritis oleh seorang cendikiawan Prancis terkemuka, Jean Baudrillard (2005). Secara umum, menurutnya, media berperan sebagai agen yang menyebar imaji-imaji kepada khalayak luas. Keputusan setiap orang untuk membeli atau tidak, benar-benar dipengaruhi oleh kekuatan imaji tersebut. Jadi motivasi untuk membeli tidak lagi berangkat dari dalam diri seseorang berdasarkan kebutuhannya yang riil, namun lebih karena adanya otoritas lain di luar dirinya yang "memaksa" untuk membeli.

Oleh karena itu, isu-isu komodifikasi, konsumerisme, sampai soal media menjadi subjeksubjek penting dalam konteks relasi kuasa di Aceh belakangan ini. Ketiga isu ini muncul secara meluas di Aceh pasca tsunami, terutama 5-10 tahun terahir. Menurut perspektif ekonomi-politik, sebagaimana penjelasan di atas bahwa isu komodifikasi, konsumerisme, hingga media ini muncul sebagai akibat dari proses ekspansi pasar yang meluas oleh agen-agen globalisasi yang tentunya telah merepresentasi pemikiran-pemikiran dan etos 
Jurnal Pemikiran Sosiologi Volume 2 No. 2, 2013

Kuasa Pasar Dalam Pembentukan Identitas Aceh: Renegosiasi Identitas Lokal dalam Praktik Komersialisasi dan

Konsumerisme Pasca Konflik dan Tsunami di Banda Aceh

Ibnu Mujib, Irwan Abdullah

kapitalisme bahkan hal ini berlangsung sebagai ideologi gerakan, bukan sekadar sebagai bentukbentuk praktik ekonomi politik yang berlangsung secara normal dan seimbang. Disinilah dominasi pasar yang praktiknya telah menghegemoni masyarakat sipil yang tidak memiliki kekuatan modal ekonomi (economic capital), dan akses politik (political access) yang cukup, bahkan negara telah begitu saja perannya dapat dibeli dengan kekuatan-kekuatan kapital yang berkuasa.

Di bawah ini akan dijelaskan bagaimana komodifikasi identitas yang terjadi di belahan Aceh, banda Aceh khususnya menjadi suatu gejala sosial ekonomi politik yang penting bagi perkembangan masyarakat Aceh, termasuk juga soal bagaimana masyarakat Aceh kini telah masuk dan terperangkap dalam mekanisme sistem pasar, yang mau tidak mau telah dipaksa dan sekaligus tunduk pada mekanisme yang diciptakan yaitu bentuk-bentuk konsumerisme yang kini sedang meluas akibat daya dukung kebijakan antar aktor dan agensi-agensi yang disepakati.

\section{B. Aceh Pasca Konflik dan Tsunami}

Menurut Irwan Abdullah (2006) setidaknya ada tiga faktor yang menyebabkan tumbuhnya gejala komersialisasi identitas di Aceh. Pertama, bahwa secara internal Aceh dan orang-orang Aceh memiliki sejarah ketidakadilan yang luar biasa, mulai dari disebabkan karena konflik berkepanjangan maupun secaranasional, hubungan-hubungan dialektis negara/pemerintah Indonesia dengan Aceh yang secara terus menerus dikonstruksi menjadi citra negatif. Kedua, bahwa orang Aceh sedang dihadapkan pada realitas baru setelah situasi sosial konflik yang berkepanjangan membuat mereka ingin lepas dari tekanan apapun, termasuk belenggu ketidakadilan selama masa transisi konflik dan tsunami. Ketiga, faktor hubunganya dengan human resources yang sedang menjajaki dan sebagian telah merasakan desakan kultur global yang cukup mewarisi berbagai sisi penting kehidupan Aceh. Human resources yang terbatas dengan tuntutan yang begitu kuat mempengaruhi mentalitas, cara berfikir, serta bahkan wisdom yang dianut sebelumnya. Dengan demikian, sistem global yang membawa pasar sebagai mekanisme kontrol atas sejarah, realitas sosial, bahkan juga termasuk sumberdaya manusia kanyataannya telah menyebabkan prinsip-prinsip lokal dan batas-batas daya dukung masyarakat kian dikesampingkan (Abdullah, 2006). Hadirnya ratusan lembaga donor ke Aceh, termasuk lembagalembaga NGO internasional, maupun sampai pada tingkat perorangan, disadari atau tidak, perannya yang tidak saja menghadirkan nilai-nilai positif karena telah membantu proses rekonstruksi dan rehabilitasi di Aceh, tetapi juga dampak interaksi antar budaya - cross cultural contact (Hannerz, 1996:112) dari masing-masing orang, lembaga, bahkan negara-negara yang terlibat di dalamnya tidak bisa dianggap sepihak. Interaksi budaya yang demikian kuat ini tentunya telah mempengruhi cara kerja dan sistem anutan, bahkan world view masyarakat Aceh secara umum. Oleh karena itu, gejala ini menuntut adaptasi panjang karena proses yang terjadi di dalamnya sangat kompleks dan bisa jadi dampaknya sampai di luar struktur budaya dan sejarah masyarakat Aceh yang menyertainya. Polapola gotong royong, kerja bakti yang sudah menjadi 
Jurnal Pemikiran Sosiologi Volume 2 No. 2, 2013

Kuasa Pasar Dalam Pembentukan Identitas Aceh: Renegosiasi Identitas Lokal dalam Praktik Komersialisasi dan

Konsumerisme Pasca Konflik dan Tsunami di Banda Aceh

Ibnu Mujib, Irwan Abdullah

kebiasaan lama masyarakat di gampong-gampong di Banda Aceh, pada saat yang sama (pasca tsunami) prinsip-prinsip komersialisasi dalam bentuk jasa berkembang secara meluas dengan bentuk "cash for work" misalnya, di mana praktiknya kemudian diperdebatkan di tingkat lokal, sebagai suatu makanisme yang ahistoris di Aceh, bahkan berlawanan dengan sistem atau mekanisme lokal yang ada sebelumnya. Perdebatan yang demikian inilah yang dalam teori sosial biasa disebut "cultural resistance". Sebuah perlawanan kultural masyarakat terhadap rejim dominan. Oleh karena itu, praktik cash for work, tidak saja didesain oleh kekuatan dominan para kapital ataupun negara donor, tetapi juga negara bertanggungjawab atas kebijakan-kebijakan kultural yang berkembang demikian sensitif ini.

\section{Komersialisasi dan Komodifikasi Nilai-Nilai, Barang dan Jasa}

Proses transformasi Aceh yang kini sedang berlangsung, baik yang dipicu oleh konflik maupun tsunami 2004 telah menandai perubahan sosial yang mengantarkan masyarakatnyapada suatu proses materialisasi (Abdullah, 2005). Prinsipprinsip yang mendasari proses materialisasi ini dapat dilihat pada dampak komersialisasi yang meluas yang diakibatkan oleh cara-cara komodifikasi yang berlangsung cukup mengejutkan di dalam masyarakat transisi Aceh, di Banda Aceh khususnya. Bentuk-bentuk komersialisasi ini tampak begitu intens terutama di awal-awal tsunami yaitu kurang lebih 1 sampai 3 tahun pasca tsunami terjadi. Beberapa contoh dapat dijelaskan, diantaranya: naiknya harga-harga bahan pokok sampai 3 kali lipat, gaji karyawan yang biasa 1-2 juta menjadi 5 juta perbulan, sehingga bahkan dampaknya sampai melahirkan pergeseran pada identitas Keacehan, seperti bagaimana masyarakat Aceh yang sebelumnya memegangi prinsip-prinsip kekeluargaan, kebersamaan, kesetiakawanan, kepedulian, dan bahkan egaliter, kemudian dipaksa dan dibenturkan pada tradisi baru yang meletakkan etos transaksional dengan mengedepankan prinsip-prinsip individual, serta bergantung pada sistem etos kapitalistis, sebuah praktik etos yang dianggap "lumrah" terjadi ditengah konteks transisi Aceh waktu itu.

Komersialisasi secara umum dalam kacamata antropologi merupakan konsepsi ekonomi politik yang muncul sebagai dampak komodifikasi nilainilai budaya, sementara komodifikasi dalam aspek budaya dapat dimaknai sebagai perubahan sebagian atau bahkan hampir seluruh budaya agar lebih komersial dan memiliki nilai jual yang tinggi yang tujuan utamanya adalah menarik minat wisatawan yang melihatnya (Ibrahim dan Idi subandi, 1997: 71). Hal ini membuat budaya tidak lagi hanya dinilai dari aspek sentimental, tetapi juga sudah dinilai dengan material (uang). Di satu sisi, masyarakat dengan berbagai komponen didalamnya berusaha melestarikan dengan tetap mempertahankan nilainilai kesakralan, tetapi di sisi lain adanya pengaruh berbagai faktor, khususnya faktor ekonomi, komersialisasi dapat meningkatkan kesejahteraan.

Oleh karena itu, gejala meluasnya komersialisasi ini diindikasi telah menyebabkan meluasnya kapitalisasi barang dan jasa, privatisasi nilai-nilai, meluasnya sikap individualisme (kota dan desa), nilai/harga barang meningkat tiga kali lipat, 
Jurnal Pemikiran Sosiologi Volume 2 No. 2, 2013

Kuasa Pasar Dalam Pembentukan Identitas Aceh: Renegosiasi Identitas Lokal dalam Praktik Komersialisasi dan

Konsumerisme Pasca Konflik dan Tsunami di Banda Aceh

Ibnu Mujib, Irwan Abdullah

termasuk gaji karyawan NGO internasional, dan sebagainya. Dampak yang muncul akibat gejala ini tidak saja berlaku di perkotaan, tetapi juga telah meluas pada kehidupan anak muda di gampong. Dengan demikian, terjadinya tsunami bagi kelompok ini tidak saja sebagai suatu bentuk yang secara normatif dipahami banyak orang sebagai krisis pada aspek sosial-ekonomi, tetapi juga menjadi sumber penghidupan baru bagi kalangan tertentu. Sebab tsunami bagi mereka telah menjadi momentum memperkuat modal ekonomi individu selain juga memperbaiki ekonomi yang telah rusak akibat konflik dan tsunami sebelumnya. Di sinilah proses renegosiasi identitas lokal juga turut mewarnai praktik-praktik komersialisasi di Banda Aceh.

Sebagai respon atas menguatnya pasar yang demikian cepat ini, secara lebih detil Irwan Abdullah (2006) juga menunjukkan bahwa pengaruh perubahan reorganisasi kehidupan terhadap orientasi identitas seperti di atas dapat dilihat pada tiga proses yang juga menjadi tanda dari keberadaan masyarakat modern. Pertama, proses materialisasi kehidupan yang mentransformasikan berbagai hal menjadi komoditas sehingga terjadi proses komodifikasi secara meluas. Kedua, tekanan sosial yang diakibatkan oleh etos kerja kapitalistik menyebabkan hidup menjadi proses mencari nilai tambah secara material. Ketiga, proses mobilitas yang menjadi fenomena terpenting di abad ke duapuluh ini mempengaruhi berbagai bentuk reorganisasi sosial, ekonomi, dan politik. Ketiga proses tersebut merupakan hal yang mendasari perubahan dalam mendefinisikan identitas dan kehidupan sebuah masyarakat (Abdullah, 2007: 8).
Proses-proses komersialisasi melalui nilai-nilai, barang dan jasa yang demikian meluas ini menjadi pilihan sistem ekonomi baru di dalam ranah masyarakat Aceh yang sedang berubah ini. Oleh karena itu, terjadinya komersialisasi di berbagai bentuk di Aceh telah menandai suatu konstruksi identitas Keacehan oleh kekuatan pasar dan para kapital. Untuk itu, setidaknya ada tiga alasan gejolak komersialisasi ini berkembang di Aceh; Pertama, bahwa pasar sangat mendominasi sistem ekonomi lain yang berkembang sebelumnya di Aceh, yaitu dengan menerapkan sistem ekonomi global yang direnegosiasikan dengan kebijakankebijakan/kearifan masyarakat setempat. Oleh karena itu, tidak heran jika dominasi pasar dan kuatnya sistem kapitalis di Aceh telah menyebabkan hilangnya identitas dan sistem ekonomi setempat. Kedua, lemahnya kontrol kekuasaan atau negara terhadap berkembangnya sistem serta terbukanya akses global dalam masyarakat transisi seperti Aceh, di sinilah peran dan kekuatan negara seolah diganti oleh kekuatan mekanisme pasar yang begitu dominan ini. Ketiga, bahwa etos komersialisasi juga memerlukan dukungan dari dalam, untuk itu gejolak komersialisasi di Aceh juga didukung oleh tuntutan kreatifitas lokal yang memang memiliki basis-basis kekuatan ekonomipolitik yang memadai. 


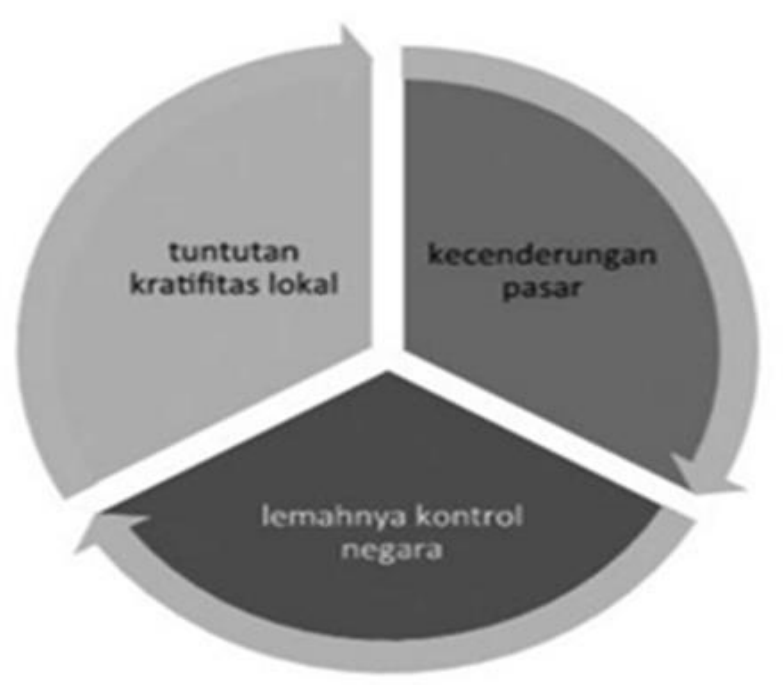

Gambar 1. Faktor Pembentuk Komersialisasi Identitas di Aceh (Sumber: olah kajian peneliti)

Sebagai mekanisme prinsip-prinsip ekonomi politik, praktik komersialisasi yang demikian meluas di Banda Aceh ini tidak saja dihembuskan oleh sistem ekonomi kapitalis yang belakangan meluas, tetapi praktiknya telah dikembangkan secara bersama dan diiringi oleh negosiasi etos kapitalis dengan sistem dan etos lokal yang ada sebelumnya secara integratif. Untuk itu, respon negara sebagai yang memiliki otoritas kekuasaan penuh mestinya dapat menyeimbangkan antara kekuatan lokal dan global yang direperesentasi masing-masing oleh masyarakat dan pasar melalui sistem ekonomi kapitalistis ini. Dengan demikian, praktik dominasi yang dilakukan oleh pasar tidak mengganggu kegiatan ekonomi lokal, di mana praktik yang juga dapat digambarkan sebagai proses kapitalisasi nilai, barang dan jasa ini terjadi karena ketidakseimbangan relasi antar-aktor, terutama terlalu dominannya pasar menjadi ketidakseimbangan dalam mengelola identitas, nilai-nilai, bahkan kepentingan-kepentingan antarindividu maupun kelompok (interest groups).

Proses kapitalisasi nilai ini diakui atau tidak telah melahirkan perubahan karakter, khususnya dengan melemahnya ikatan-ikatan tradisional yang kerananya memberi otonomi yang lebih besar pada individu-individu (Goldsmith, 1998). Oleh kerena itu, tidak bisa dipungkiri bahwa persoalan kemanusiaan menjadi lebih penting terutama dalam konteks global di Aceh. Fakta tentang gejolak komersialisasi yang demikian menguat ini harus dilekatkan dengan proses pemanusiaan etis yang kini di Aceh mulai mengabur. Di mana suatu proses sosial yang didasari prinsip-prinsip individual biasanya akan melahirkan kesenjangan sosial di dalam penataan sosial suatu masyarakat.

Oleh karena itu, posisi negara bersama-sama masyarakat kenyataannya tidak mampu meletakkan kekuasaanya sebagai kontrol atas tindakan ekonomi yang berbasis kapitalistis ini, sehingga pasar bisa menjadi penguasa dalam aktifitas ekonomi politik di Aceh kaitannya dengan prinsip-prinsip komersialisasi dan komodifikasi ini, terutama bagaimana ketika lokal atau Aceh harus mempertahankan kelangsungan identitasnya, dan juga bagaiamana ketika lokal atau Aceh harus melewati proses sosial yang melekatkan nilai-nilai kearifan tradisional pada masyarakatnya, pada saat yang sama digantikan dengan prinsip-prinsip ekonomi pasar/global. Di sinilah proses negosiasi antar-aktor dan agensi-agensi bahkan kadang berjalan di tempat, kemudian masyarakat dituntut untuk mengikuti saja kemauan selera pasar. Hal ini terjadi ketika negara dan masyarakat lemah 
Jurnal Pemikiran Sosiologi Volume 2 No. 2, 2013

Kuasa Pasar Dalam Pembentukan Identitas Aceh: Renegosiasi Identitas Lokal dalam Praktik Komersialisasi dan

Konsumerisme Pasca Konflik dan Tsunami di Banda Aceh

Ibnu Mujib, Irwan Abdullah

memfungsikan kekuasaanya kembali, karena pasar terlalu dominan mengendalikan modal (Bourdieu, 1997).

Di bawah ini akan dikaji bagaimana aspek lain yang melatarbelakangi meluasnya praktik kuasa pasar yang begitu tampak dominan, yaitu salah satunya adalah mengenai praktik konsumerisme atau dalam bentuk lain juga disebut konsumtivisme. Di mana kenyataannya telah memperlihatkan suatu efek sosial-ekonomi yang mengundang "konflik" atau persoalan identitas di dalamnya, terutama antara identitas lokal dan prinsip-prinsip global yang mendorong semangat etos kapitalisasi atas modal. Konsumtivisme menjadi isu yang cukup hangat didiskusikan, terlebih menjadi suatu proses pembentukan gaya hidup suatu masyarakat, terutama di Banda Aceh.

\section{Konsumerisme: Bias Kuasa Pasar dalam Pembentukan Gaya Hidup}

Masyarakat Aceh kini telah dihadapkan pada satu situasi yang relatif memiliki kecenderungan baru, yaitu apa biasa disebut konsumtivisme "konsumerisme". Kecenderungan baru ini tidak saja lahir dari latar belakang tatanan sosial yang menganut sistem dan prinsip etos kerja kapitalistik, tetapi juga muncul dari sebuah desain hegemoni pasar yang muncul secara dominan seperti apa yang terjadi di Aceh, sehingga menyebabkan munculnya konsumtivisme. Dalam era konsumerisme kontestasi untuk memperebutkan (konsumsi dan simbol-simbol) menjadi sebuah kapital yang terus direproduksi setiap saat oleh masyarakat modern
(Bourdieu,1984), sebab ada sebuah keyakinan bahwa "dengan memiliki dan memakai atau mengkonsumsi suatu benda tertentu merupakan suatu proses untuk mengidentifikasikan diri sendiri sebagai bentuk pembeda dengan orang lain".

Oleh karena itu, dari proses identifikasi diri inilah kemudian praktik ini melahirkan apa yang disebut gaya hidup (lifestyle). Gejala pembentukan gaya hidup ini secara tidak langsung mengungkapkan sebuah batasan-batasan kultural yang menekankan gaya hidup sebagai sub kultur dalam masyarakat Aceh, selain itu gaya hidup juga merupakan proses komunikasi, sehingga gaya hidup merupakan usaha untuk menghadirkan makna identitas diri yang dihadirkan lewat simbolsimbol tertentu seperti barang yang dikenakan, pemanfaatan waktu luang dan hal lainnya. Hal ini lagi-lagi ditegaskan oleh Spradley dan Geertz (1973) bahwa semua makna budaya diciptakan dengan menggunakan simbol-simbol. Oleh karena itu, gaya hidup haruslah dilihat sebagai suatu proses komunikasi lintas budaya dalam interaksi sosial masyarakat, sebab ia menggunakan sejumlah tanda atau simbol sebagai mediumnya.

Kembali pada persoalan konsumsi, atau sebut saja dengan belanja. Belanja semula hanya merupakan suatu konsep yang menunjukkan suatu sikap untuk mendapatkan barang-barang sebagai keperluan sehari-hari dengan jalan menukarkan sejumlah uang sebagai pengganti barang tersebut (Guiry dan Luzt, 2000: 132). Akan tetapi, konsep belanja itu sendiri telah berkembang sebagai sebuah cerminan gaya hidup dan rekreasi di kalangan masyarakat. Belanja merupakan suatu gaya hidup tersendiri, yang bahkan menjadi suatu kegemaran 
Jurnal Pemikiran Sosiologi Volume 2 No. 2, 2013

Kuasa Pasar Dalam Pembentukan Identitas Aceh: Renegosiasi Identitas Lokal dalam Praktik Komersialisasi dan

Konsumerisme Pasca Konflik dan Tsunami di Banda Aceh

Ibnu Mujib, Irwan Abdullah

bagi sejumlah orang (Guiry dan Luzt, 2000: 172). Gejolak konsumerisme ini muncul bisa dilihat pada gejala yang meluas di kalangan anak muda Banda Aceh pasca tsunami, tradisi belanja yang biasanya cukup dilakukan di tempat-tempat perbelanjaan di Banda Aceh, kini bergeser ke mall-mall yang ada di Bali, Malaysia, Singgapore, Jakarta, dan sebagainya.

Ethos konsumerisme ini juga dapat dilihat dalam praktik keseharian masyarakat Banda Aceh, terutama anak- anak remaja dari putri-putri mereka yang mulai menginjak dewasa. Semangat konsumerisme tumbuh tidak lagi hanya menjadi bagian yang membentuk resistensi kultural (cultural resistance) dalam masyarakat, tetapi ia tumbuh menjadi gaya hidup (lifestyle), cara berfikir, serta menjadi tuntutan komunitas heterogen yang bisa jadi dipicu oleh paket industrialisasi media yang menjamur di kalangan masyarakat, seperti: televisi, internet, majalah, termasuk media cetak seperti koran dan sebagainya. Mereka tidak hanya tertarik oleh diskon yang ditawarkan oleh para produsen, akan tetapi juga didukung dengan kemasan produk yang menarik pula. Pada batas inilah selera pasar menjadi penentu, mereka adalah subjek yang mendesain keinginan para shopper (konsumen), dan pada saat yang sama konsumen telah dipaksa dengan pilihan-pilihan yang menurut selera pasar akan menguatkan kapasitas modal yang dimiliki. Begitulah cara kerja sistem ekonomi kapitalistis yang kini sedang berlangsung bersama proses sosial-politik di Banda Aceh.
Ketertarikan dalam hal berbelanja di kalangan anak muda Aceh ini tidak jarang dipicu oleh mudahnya mereka mendapatkan uang. Akses ekonomi masyarakat Aceh berubah ketika datangnya para relawan dan donatur dalam program rehabilitasi dan rekonstruksi Aceh. Kemudahan itu juga bisa diciptakan oleh sistem ekonomi asing yang menggunakan standarisasi "angka ekonomi" yang berbeda cukup tajam dengan standar lokal. Selain mekanisme asing menyebabkan perbedaanperbedaan dalam tingkat penggunaan aspek finansial di tingkat lokal, sistem ekonomi asing juga melahirkan gejolak kesenjangan bagi masyarakat/individu yang tidak mendapatkan akses ekonomi yang sama. Oleh karena itu, pasar lagi-lagi telah menciptakan praktik-praktik kemudahan dalam mendukung praktik konsumtivisme disatu sisi, di sisis lain pasar juga telah mengabaikan standar-standar ekonomi lokal yang telah ada sebelumnya. Bisa dibayangkan, gaji seorang pekerja security yang biasanya Rp $1.500 .000-2.000 .000$ sebelum tsunami, kini pasca krisis tsunami naik hampir 3 kali lipat, sehingga tiap bulan seorang security bisa menghasilkan gaji 5 juta perbulan. Tidak berbeda dengan seorang penjual kopi di warung-warung kopi tradisional di Banda Aceh. Di warung kopi "de Helsinki" misalnya sebelum tsunami omset rata-rata per hari maksimal, di antara 500.000/hari, pasca krisis mereka dapat 2-3 juta perhari. Oleh karena itu, tidak heran jika akumulasi kapital dari sebuah proses komodifikasi di atas telah menciptakan arus baru yang disebut dengan era konsumerisme menuju masyarakat konsumtif. 
Jurnal Pemikiran Sosiologi Volume 2 No. 2, 2013

Kuasa Pasar Dalam Pembentukan Identitas Aceh: Renegosiasi Identitas Lokal dalam Praktik Komersialisasi dan

Konsumerisme Pasca Konflik dan Tsunami di Banda Aceh

Ibnu Mujib, Irwan Abdullah

Bentuk-bentuk komodifikasi nilai, barang dan jasa yang diiringi perkembangannya oleh aspek-aspek konsumerisme semacam ini setidaknya dapat dilihat dari perkembangan kapital ekonomi masyarakat Aceh yang cenderung meningkat. Hal ini dibentuk oleh paling tidak tiga kekuatan penting dalalm proses sosial suatu komunitas, Pertama, munculnya ekspansi global terutama pasca tsunami yang semakin menguat. Kedua, ditandai dengan kemenangan agen-agen kapital dalam menegosiasikan produk-produk yang ditawarkan. Ketiga, tingkat mobilitas eksternal yang cenderung lebih beragam dan heterogen. Ketiga kekuatan ini merupakan suatu kesatuan yang membentuk masyarakat Aceh menjadi konsumeris, di mana kekuatan ekspansi global sebagai desainer pendukung utamanya, sedangkan agensi berperan yang mengkontestasikan antara produk-produk lokal-dan global, sementara mobilitas eksternal yang beragam menjadi kekuatan dari luar yang merangsang tumbuhnya para konsumeris baru. Untuk itu, pembentukan identitas sebagai masyarakat konsumtif maupun yang menghayatinya sebagai gaya hidup telah direproduksi secara terus menerus oleh market yang didukung oleh kekuatankekuatan baru.

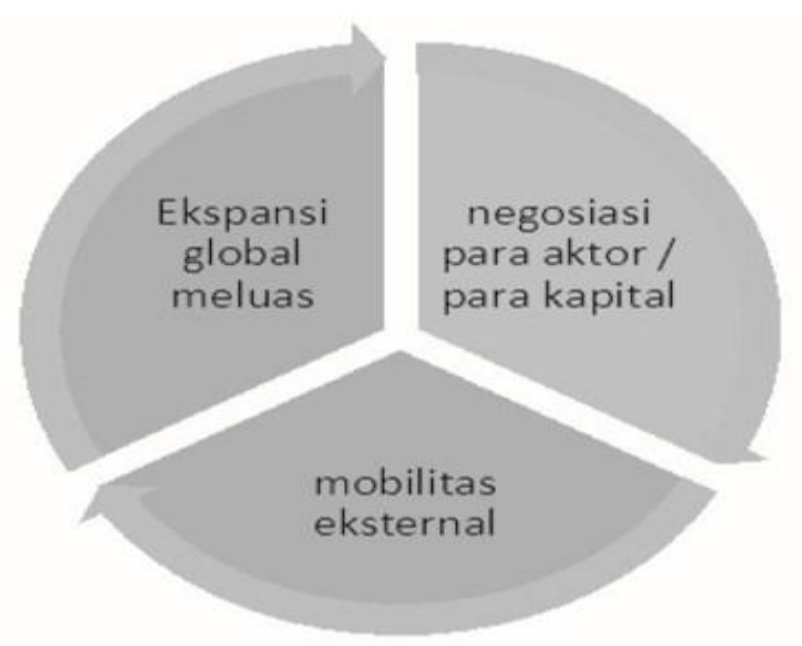

Gambar 2. Tiga Pembentuk Etos Konsumerisme di Aceh (sumber: olah kajian peneliti)

Oleh karena itu, lebih lanjut persoalan yang penting untuk kita lihat dari ethos konsumerisme ini adalah bahwa basis ekonomi-politik yang dibangun oleh kekuatan pasar ini tidak sekedar memperlihatkan kekurangan ataupun kelebihan yang diakibatkannya, akan tetapi aspek-aspek kultural dari yang harus diterima masyarakat juga harus menjadi perhatian tersendiri. Interaksi tatap muka misalnya yang kini telah digantikan dengan peranperan teknologi informasi seperti handphone, belum lagi internet dengan fasilitas-fasilitas yang dimiliki seperti facebook, twitter dan sejenisnya, cepat atau lambat gejala ini semakin menunjukkan kecenderungan pasar yang tidak saja memperlakukan setiap orang sebagai konsumen, tetapi pasar juga mengajarkan seseorang untuk berdemokrasi dan kebebasan individu (Abdullah, 2006: 144). 
Jurnal Pemikiran Sosiologi Volume 2 No. 2, 2013

Kuasa Pasar Dalam Pembentukan Identitas Aceh: Renegosiasi Identitas Lokal dalam Praktik Komersialisasi dan

Konsumerisme Pasca Konflik dan Tsunami di Banda Aceh

Ibnu Mujib, Irwan Abdullah

\section{E. Kesimpulan}

Sebagai bagian dari prinsip-prinsip ekonomi politik, praktik komersialisasi yang demikian meluas ini tidak saja dihembuskan oleh sistem ekonomi kapitalis, tetapi praktiknya telah dikembangkan secara bersamaan dan diiringi dengan negosiasi-negosiasi panjang antara etos kapitalis dengan sistem dan etos lokal yang ada sebelumnya secara integratif. Untuk itu, respon negara sebagai yang memiliki otoritas kekuasaan penuh mestinya dapat menyeimbangkan antara kekuatan lokal dan global yang direperesentasi masing-masing oleh masyarakat dan pasar melalui sistem ekonomi kapitalistis ini. Praktik dominasi yang dilakukan oleh pasar tidak mengganggu kegiatan ekonomi lokal, di mana praktik yang juga dapat digambarkan sebagai proses kapitalisasi nilai, barang dan jasa ini terjadi karena ketidakseimbangan relasi antar-aktor, terutama terlalu dominannya pasar menjadi ketidakseimbangan dalam mengelola identitas, nilai-nilai, bahkan kepentingan-kepentingan antarindividu maupun kelompok.

Oleh karena itu, pasar bisa menjadi penguasa dalam aktifitas ekonomi politik kaitannya dengan prinsipprinsip komersialisasi dan komodifikasi ini, terutama bagaimana ketika lokal harus mempertahankan kelangsungan identitasnya, dan juga bagaiamana ketika lokal harus melewati proses sosial yang melekatkan nilai-nilai kearifan tradisional, pada saat yang sama digantikan dengan prinsip-prinsipekonomi pasar/global. Disinilah proses negosiasi antar-aktor dan agensi-agensi bahkan kadang tidak berjalan, kemudian masyarakat dituntut untuk mengikuti saja kemauan selera pasar.Hal ini terjadi ketika negara dan masyarakat lemah memfungsikan kekuasaanya kembali, karena pasar terlalu dominan mengendalikan modal.

Selain itu, bias kuasa pasar juga bisa dilihat dalam praktik konsumerisme, merupakan sisi lain yang dapat dimaknai sebagai subjek yang lahir dari rahim komersialisasi. Semangat konsumerisme tumbuh tidak lagi hanya menjadi bagian yang membentuk yang membentuk resistensi kultural (cultural resistance) dalam masyarakat, tetapi ia tumbuh menjadi gaya hidup (lifestyle), cara berfikir, serta menjadi tuntutan komunitas heterogen yang bisa jadi dipicu oleh paket industrialisasi media yang menjamur di kalangan masyarakat, seperti: televisi, internet, majalah, termasuk media cetak seperti koran dan sebagainya. Pada batas inilah selera pasar menjadi penentu, mereka adalah subjek yang mendesain keinginan para shopper (konsumen), dan pada saat yang sama konsumen telah dipaksa dengan pilihan-pilihan yang menurut selera pasar akan menguatkan kapasitas modal yang dimiliki. Begitulah cara kerja sistem ekonomi kapitalistis yang kini sedang berlangsung bersama proses sosial dan ekonomi politik di Banda Aceh. Oleh karena itu, intensitas dialog, sampai renegosiasi identitas lokal-global menjadi suatu modal konstruksi pasar yang penting dalam meletakkan dasar-dasar keseimbangan antar kepantingan pada aras lokal dan global, sehingga kuasa pasar dapat dikendalikan oleh kekuatan-kekuatan yang berasal dari negara maupun masyarakat sendiri. 
Jurnal Pemikiran Sosiologi Volume 2 No. 2, 2013

Kuasa Pasar Dalam Pembentukan Identitas Aceh: Renegosiasi Identitas Lokal dalam Praktik Komersialisasi dan

Konsumerisme Pasca Konflik dan Tsunami di Banda Aceh

Ibnu Mujib, Irwan Abdullah

\section{Daftar Pustaka}

Abdullah, Irwan. 1998. "Antropologi di Persimpangan Jalan. Refleksi dari Pemahaman atas Tindakan kaum Muda", Antropologi Indonesia Vol. 21 No 54. 2006. Konstruksi dan Reproduksi Kebudayaan. Yogyakarta: Pustaka Pelajar. 2007. "Potret Retak Komunalisme: Aceh sebagai Field of Study Kebudayaan." Makalah diskusi disampaikan pada. Wednesday Forum CRCS.

Appadurai, Arjun. 1994. "Global Ethnoscapes: Note and Quaries for Transnational Anthropology" dalam R.G. Fox (ed) Recapturing Anthopology: working in the Present. Santa fe, NM: School of American Research Press.

Benzer, Matthias. 2011. The Sociology of Theodor Adorno. New York:Cambridge University Press,

Beyer, Peter. F.1991."Privatization and the Public Influence of Religion in Global Society", dalam Mike Featherstone (ed), Global Culture: Nationalism, Globalization and Modernity. London: Sage Publication

Bourdieu, Pierre. 1993. The Field of Cultural Production: Essays on Art and Leissure, New York: Columbia University Press.

Friedmen, Jonathan. 1991. "Being in the World; Globalization and Localization", dalam Mike Fatherstone (ed) Global Culture; Nationalism, Globalization, and Modernity. London: Sage publication.

Geertz, Cliford 1983. Local Knowledge. New York: Basic Book.
Gramsci, Antonio. 1971. Selection from Prison Notebooks. Edited and translated by Quintine Hoare and Geofey Nowel Smith. London: Lowrence and Wishart.

Golsmith, Marshall. 1998. "Global Communication and Community of Choice", dalam F. Hesselbein, et al (ed) Community of the Future. San Fancisco: Jossy-Bass Publication

Guiry, Michael and Richard J. Lutz. 2000. Recreational Shopper Identity: Implication of Recreational Shopping for Consumer Self Definition. USA: University of Florida

Hall, Stuart, 1990. "Cultural Identity and Diaspora", dalam Jonathan Rutherford (ed), Identity: Community, Culture, and Difference. London: Lawrence and Wishard

1991. "The Local and Global: Globalization and Ethnicity; Old and new Identity, Old and New Ethnicity," dalam Anthony D. King (ed) Culture, Globalization and the World System. London: Macmillan.

Hannerz, Ulf. 1992. Cultural Complexity, NewYork: Colombia University Press. 1996. Transnational Connection, Culture, People, Place. London: Routledge

Ibrahim, Idi Subandi. 1997. Ecstasy dan Gaya Hidup: Kebudayaan Pop dalam Masyarakat Komoditi. Bandung: Mizan.

Lindsey. Lawrence B. 1998. "The Real Economic Globalist". Far Eastern Economic Review, 26 Maret.

Livesey, C. 2004, “Culture and Identity”, Sociological Pathways.

http://www.sociology.org.uk/pathway2.ht m. Diakses 10 Juni 2013. 
Jurnal Pemikiran Sosiologi Volume 2 No. 2, 2013

Kuasa Pasar Dalam Pembentukan Identitas Aceh: Renegosiasi Identitas Lokal dalam Praktik Komersialisasi dan

Konsumerisme Pasca Konflik dan Tsunami di Banda Aceh

Ibnu Mujib, Irwan Abdullah

Morris, Christopher W. 1999. The Social Contract Theorists: Critical Essays on Hobbes, Locke, and Rousseau. Lanham,Md:

Rowman\&Littlefield

Riddell. Peter G. 2006. "Serambi Mekkah" dan Identity, dalam Anthony Reid, Verandah of Violance. Singgapure: NUS press

Ritzer, George dan Goodman, Douglas J. (Terjemahan Nurhadi). 2010. Teori Sosiologi: Dari Teori Sosiologi Klasik Sampai Perkembangan Mutakhir Teori Sosial Postmodern, Yogyakarta: Kreasi Wacana.

Wahyuni, Hermin Indah, 2000. "Relasi MediaNegara-Masyarakat dan Pasar". Jurnal IImu Sosial \& Ilmu Politik, Vol. 4 No 2, November. 